\title{
UPAYA MENINGKATKAN KECERDASAN INTERPERSONAL ANAK MELALUI METODE BERMAIN PERAN DI RA DHARMA WANITA PERSATUAN (DWP) STAIN DATOKARAMA PALU
}

\author{
Bella Safitri ${ }^{1)}$ Rustam $^{2)}$ Hikmatur Rahmah ${ }^{3)}$ \\ ${ }^{1}$ Mahasiswa Program Studi PIAUD FTIK Institut Agama Islam Negeri Palu \\ ${ }^{2}$ Dosen Fakultas Tarbiyah dan Ilmu Keguruan Institut Agama Islam Negeri Palu \\ ${ }^{3}$ Dosen Fakultas Tarbiyah dan Ilmu Keguruan Institut Agama Islam Negeri Palu
}

\begin{abstract}
ABSTRAK
Penelitian ini bertujuan untuk mengetahui upaya meningkatkan kecerdasan interpersonal anak melalui metode bermain peran di RA DWP STAIN Datokarama Palu dan mengetahui peningkatan kecerdasan interpersonal anak melalui metode bermain peran di RA DWP STAIN Datokarama Palu. Penelitian ini mengunakan metode Penelitian Tindakan Kelas (PTK). Teknik pengumpulan data melalui observasi, dokumentasi dan wawancara. Teknik analisis melalui lembar observasi pada siklus I dan siklus II setelah data terkumpul, lalu di analisa secara kualitatif dan kuantitatif untuk mengetahui tentang ada tidaknya peningkatan kecerdasan interpersonal anak melalui metode bermain peran. Hasil penelitian menunjukan bahwa kecerdasan interpersonal anak meningkat setelah adanya tindakan melalui metode bermain peran. Pada saat dilakukan observasi pra tindakan, presentase kecerdasan interpersonal anak sebesar 13,88\%, kemudian belum mengalami peningkatan pada siklus I tindakan I 13,88\%, kemudian mulai meningkat pada siklus I tindakan II 27,79\%. Pada pelaksaan siklus II juga mengalami peningkatan $55,56 \%$ dan kemudian terjadi peningkatan yang sangat baik pada siklus II tindakan II 83,33\%. Berdasarkan hasil tersebut disimpulkan bahwa metode bermain peran dapat digunakan untuk meningkatkan kecerdasan interpersonal anak di RA DWP STAIN Datokarama palu.
\end{abstract}

Kata Kunci : Kecerdasan interpersonal, Metode bermain peran

\section{PENDAHULUAN}

Kecerdasan interpersonal di artikan sebagai kecerdasan dalam diri untuk mengenali dan memahami dirinya sendiri. Kecerdasan interpersonal juga membantu sesorang mengenali diri dan batasan dirinya sendiri sehingga dapat mengekspresikan diri dengan baik saat interaksi dalam kehidupan. Metode bermain peran ini dikategorikan sebagai metode belajar yang berumpun kepada metode perilaku yang diterapkan dalam kegiatan pengembangan. Karakteristiknya adalah adanya kecenderungan memecahkan tugas belajar dalam sejumlah perilaku yang berurutan, konkret dan dapat diamati. Di RA DWP STAIN Datokarama Palu mengenai kecerdasan interpersonal anak masih minim. Hal ini tampak dimana 
kemampuan dalam berinteraksi dengan teman sebaya masih kurang, anak tidak mau bermain dengan teman yang lain yang bukan teman dekatnya. Kerja sama saat bermain masih minim. Banyak anak dikelas yang hanya bermain secara individu, tanpa adanya kerja sama dengan teman yang lain.

Dewasa ini pertumbuhan anak TK mendapat perhatian serius terutama dari pemerintah, karena disadari benar bahwa merekalah yang akan menjadi penerus generasi yang sekarang. Paradigma lama dengan guru sebagai pusat kegiatan sudah mulai di tinggalkan, banyak hasil penelitian membuktikan bahwa para guru sudah harus mengubah paradigma dalam pengajarannya. Seorang pendidik harus didukung dengan kompetensi yang dimiliki. Jika seorang pendidik tidak memiliki kompetensi dalam bidang pendidikan, maka dapat dipastikan peserta didik tidak akan mendapatkan apa yang ia inginkan, begitupun dengan dunia pendidikan tidak akan mampu mencapai tujuan yang diharapkan.

Dalam Undang-undang No. 20 Tahun 2003 tentang sistem pendidikan nasional Bab 1, Pasal 1, Butir 14 yang mengatakan bahwa pendidikan anak usia dini adalah upaya pembinaan yang ditujukan kepada anak sejak lahir sampai dengan usia 6 tahun yang di lakukan melalui pemberian ransangan pendidikan untuk membantu pertumbuhan dan perkembangan jasmani dan rohani agar anak memiliki kesiapan untuk memasuki pendidikan lebih lanjut. ${ }^{1}$

Metode bermain peran ini dikategorikan sebagai metode belajar yang berumpun kepada metode perilaku yang diterapkan dalam kegiatan pengembangan. Karakteristiknya adalah adanya kecenderungan memecahkan tugas belajar dalam sejumlah perilaku yang berurutan, konkret dan dapat di amati.

Adapun ayat Al-Qur'an yang menjelaskan tentang metode pembelajaran dalam Q.S An-Nahl [14]: 125

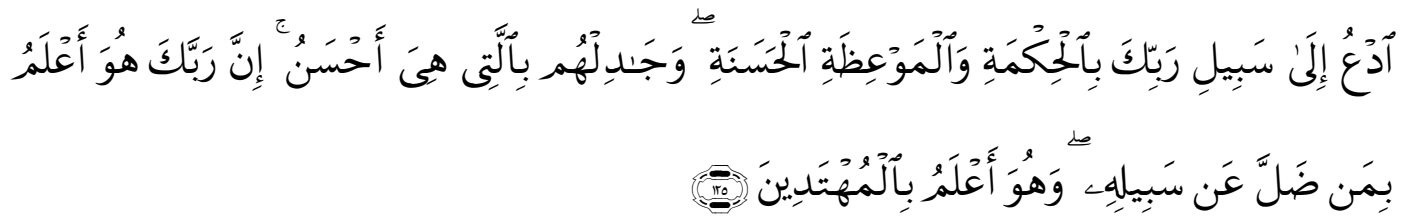

Terjemahannya:

"Serulah (manusia) kepada jalan Tuhanmu dengan hikmah dan pengajaran yang baik, dan berdebatlah dengan mereka dengan cara yang baik. Sesunguhnya Tuhanmu, dialah yang lebih mengetahui siapa yang sesat dari jalan-Nya dan Tafsiran : dialah yang lebih mengetahui siapa yang mendapat petunjuk.

Ajaklah wahai rasul kepada agama islam, kamu dan orang-orang beriman yang mengikutimu dengan cara yang sesuai dengan keadaan objek dakwah, pemahaman dan ketundukannya, melalui nasihat yang mengandung motivasi dan peringatan, debatlah mereka dengan cara yang lebih baik dari sisi perkataan, ${ }^{1}$ Undang-undang Nomor 20 Tahun 2003, Tentang Sistem Pendidikan nasional Bab 1,
pasal 1, Butir 14, (2003) 
pemikiran dan pengkondisian. Kamu tidak bertugas memberi manusia hidayah, akan tetapi tugasmu hanya menyampaikan kepada mereka. Sesungguhnnya rabbmu lebih mengetahui siapa yang tersesat dari agama islam dan dia lebih mengetahui siapa yang mendapat petunjuk, karena itu jangan sia-siakan dirimu dengan kesedihan mendalam atas mereka.

Adapun ayat Al-Qur'an yang menjelaskan tentang metode pembelajaran dalam Q.S Lukman [21]: 13

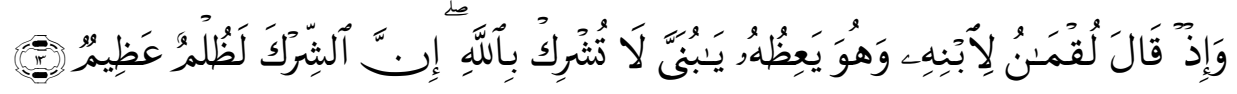

Terjemahannya :

"dan (ingatlah) ketika Luqman berkata kepada anaknya, di waktu ia memberi pelajaran kepadanya: "Hai anakku, janganlah kamu mempersekutukan Allah, Sesungguhnya mempersekutukan (Allah) adalah benar-benar kezaliman yang besar".

Tafsiran :

Ingatlah wahai Rasul tatkala Lukman berkata kepada anaknya, dan dia menginginkannya dari keburukan, "Wahai anakku! Janganlah engkau menyembah sesembahan lain selain Allah adalah kezaliman yang besar terhadap jiwa dengan melakukan dosa terbesar yang mengakibatkan kekal di dalam neraka.

Pengunaan metode ini juga memupuk adanya pemahaman peran sosial dan melibatkan interaksi verbal yang paling tidak dengan satu orang lain. Mereka juga banyak belajar dari temannya tentang cara-cara berinteraksi dalam kondisi sosiodramatik. Selain itu, mereka juga belajar berkonsentrasi dalam satu tema drama untuk waktu tertentu. ${ }^{2}$

\section{METODE PENELITIAN}

Peneliti dalam melakukan penelitian ini menggunakan metode penelitian tindakan kelas. penelitian tindakan kelas (PTK) adalah kegiatan mengumpulkan, mengolah, menganalisis, dan menyimpulkan data untuk menentukan tingkat keberhasilan jenis tindakan yang dilaksanakan oleh guru dalam proses pembelajaran.

Penelitian ini dilaksanakan di RA DWP STAIN Datokarama Palu. Subjek dalam Penelitian Tindakan Kelas ini siswa RA DWP STAIN Datokarama Palu dengan jumlah siswa 17 orang terdiri dari 10 laki-laki dan 7 perempuan. Tetapi dalam hal ini hanya 12 orang siswa yang diteliti, dikarenakan lima orang yang tidak aktif.

${ }^{2}$ Winda Gunarti, S.Pd, Lilis Suryani, S.Pd, Azizah Muis, S.Pd, Metode Pengembangan Perilaku dan Kemampuan Dasar Anak Usia Dini (Jakarta: Universitas Terbuka, 2010).10.11 
Teknik pengumpulan data yang digunakan adalah teknik observasi, dokumentasi dan wawancara. Adapun teknik analisis data melalui lembar observasi pada siklus I dan siklus II setelah data terkumpul, lalu di analisa secara kualitatif dan kuantitatif untuk mengetahui tentang ada tidaknya peningkatan kecerdasan interpersonal anak melalui metode bermain peran.

\section{HASIL DAN PEMBAHASAN}

\section{A. Hasil Penelitian}

\section{Pra Tindakan}

Langkah awal dari penelitian ini, penulis melakukan observasi awal, untuk melihat sampai dimana peningkatan dan perkembangan kemampuan anak dalam metode bermain peran. Kegiatan pra tindakan umunya dilakukan sebelum penulis memulai penelitian terhadap Upaya Meningkatkan Kecerdasan Interpersonal Anak Melalui Metode Bermain Peran di RA DWP STAIN Datokarama Palu. Pada saat pra tindakan di lakukan oleh penulis di RA DWP STAIN Datokarama Palu. Peserta didik yang hadir berjumlah 12 anak. Ada pun yang penulis amati di RA DWP STAIN Datokarama Palu yaitu peserta didik bisa menyesuaikan diri, empati, dan kooperatif/kerja sama.

Dari hasil pengamatan dapat di ketahui dari 12 peserta didik yang menjadi subjek penelitian untuk kemampuan menyesuaikan diri terdapat 2 peserta didik (16.66\%) dalam kategori Berkambang Sangat Baik (BSB) karena anak bersosialisai dengan teman-teman sejawad dan orang lain, 3 peserta didik (25\%) dalam kategori Berkembang Sesuai Harapan (BSH) karena anak dapat bersosialisasi dengan teman sejawat tanpa memilih, 4 peserta didik (33.34\%) dalam kategori Mulai Berkembang (MB) karena anak hanya bersosialisai dengan teman-teman tertentu, 3 peserta didik (25\%) kategori Belum Berkembang (BB) karena anak kurang bersosialisai dengan teman sejawat dan oarang lain.

Dari hasil pengamatan juga dapat diketahui dari 12 peserta didik yang menjadi subjek penelitian untuk kemampuan empati terdapat 1 peserta didik $(8,34 \%)$ dalam kategori Berkambang Sangat Baik (BSB) karena anak menghibur teman yang sedih, 2 peserta didik (16,66\%) dalam kategori Berkembang Sesuai Harapan (BSH) karena anak menghibur teman yang sedih tanpa memilih, 4 peserta didik $(33,34 \%)$ dalam kategori Mulai Berkembang (MB) karena anak hanya menghibur teman tertentu, 5 peserta didik (41,66\%) kategori Belum Berkembang (BB) karena anak tidak menghibur teman yang sedih.

Berdasarkan hasil pengamatan dapat diketahui dari 12 peserta didik yang menjadi subjek penelitian untuk meningkatkan empati terdapat 2 peserta didik $(16,66 \%)$ dalam kategori Berkambang Sangat Baik (BSB) karena anak melakukan tugas secara bersama, 3 peserta didik (25\%) dalam kategori Berkembang Sesuai Harapan (BSH) karena anak melakukan tugas secara bersama tanpa memilih, 3 
peserta didik (25\%) dalam kategori Mulai Berkembang (MB) karena anak melakukan tugas tertentu, 4 peserta didik $(33,34 \%)$ kategori Belum Berkembang (BB) karena anak tidak melakukan tugas secara bersama.

Dengan demikian, setelah di rata-ratakan ketiga aspek yang diamati, terdapat $13.88 \%$ dalam kategori Berkembang Sangat Baik (BSB), 22,22\% dalam kategori Berkembang Sesuai Harapan (BSH), 30,56\% dalam kategori Mulai Berkembang (MB), dan 33,33\% dalam kategori Belum Berkembang (BB). Setelah melihat hasil nilai rata-rata yang telah dijelaskan pada pra tindakan di RA DWP STAIN Datokaram Palu, dapat dilihat sedikit anak yang memiliki kecerdasan interpersonal yang baik karena masih banyak anak yang belum memiliki kemampuan menyesuaikan diri, empati, dan kooperatif/kerja sama. Berdasarkan permasalahan tersebut, maka peneliti melaksanakan penelitian tindakan kelas dengan harapan dapat meningkatkan kecerdasan interpersonal anak melalui metode bermain peran.

\section{Hasil Pengamatan Siklus I}

Pada tahap tindakan siklus I ini, penulis melakukan proses belajar mengajar didalam kelas berdasarkan RPPH yang telah penulis buat untuk meningkatkan keceradasan interpersonal anak melalui metode bermain peran didalam tindakan siklus 1 ini. Penulis melakukan tindakan I dan II pada siklus I ini, dimulai dengan membuat perencanaan, tindakan, observasi, dan refleksi. Saat penyajian materi, peneliti bertindak sebagai pengajar.

\section{a. Perencanaan}

Pada tahap ini, peneliti mempersiapkan tindakan seperti:

1) Memilih materi yang akan diajarkan sesuai dengan tema

2) Membuat rencana kegiatan harian (RPPH)

3) Membuat lembar observasi aktivitas guru dan murid

4) Mempersiapkan alat bantu mengajar dan alat permainan edukatif

5) Membuat tugas yang akan dikerjakan

\section{b. Pelaksanaan}

Melaksanakan proses pembelajaran di dalam kelas berdasarkan RPPH yang telah dibuat, yaitu melaksanakan kegiatan pembuka 30 menit yang dimulai dengan mengucapkan salam, berdoa, membaca surah annas ayat 1-2 dan Melafalkan Do'a sebelum belajar. Setelah membaca doa masuk kegiatan inti selama 60 menit. Dalam pembelajaran inti selama 60 menit yang dimulai dengan bertanya tentang hari, tanggal, bulan dan tahun, dan dilanjutkan dengan menjelaskan tema hari ini, kemudian kegiatan belajar dan bermain peran dokter-dokter.

Setelah selesai pembelajaran, masuk kegiatan istirahat 30 menit masuk kegiatan Berdo'a sebelum dan sesudah makan, Bermain di dalam / di luar kelas. Setelah istirahat masuk kegiatan penutup 60 menit Diskusi kegiatan hari ini, bernyanyi dan bersyair pulang sekolah, Berdo'a pulang dan Salam. 


\section{c. Observasi}

Penulis melakukan pengamatan terhadap aktivitas anak pada saat proses kegaiatan pembelajaran berlangsung, adapun hasil pengamatan tindakan I dan II pada aktivitas peserta didik di RA DWP STAIN Datokarama Palu.

Berdasarkan hasil penelitian, diketahui dari 12 anak meningkat kecerdasan interpersonal anak dalam menyesuaikan diri melalui siklus I tindakan I terdapat 2 peserta didik $(16,66 \%)$ dalam ketegori Berkembang Sangat Baik (BSB) karena anak bersosialisi dengan tema-teman sejawad dan orang lain, 3 peserta didik $(25 \%)$ dalam kategori Berkembang Sesuai Harapan (BSH) karena anak bersosialisasi dengan temanteman sejawad dan orang lain tanpa memilih, 4 peserta didik $(33,34 \%)$ dalam kategori Mulai Berkembang (MB) karena anak hanya bersosialisasi dengan teman-teman tertentu, 3 peserta didik (25\%) dalam kategori Belum Berkembang (BB) karena anak kurang bersosialisasi dengan teman-teman sejawat dan orang lain.

Meningkatkan kecerdasan interpersonal anak dalam empati, terdapat $1(8,34 \%)$ dalam ketegori Berkembang Sangat Baik (BSB) karena anak menghibur teman yang sedih, 6 peserta didik (50\%) dalam kategori Berkembang Sesuai Harapan (BSH) karena anak menghibur teman yang sedih tanpa memilih, 3 peserta didik (25\%) dalam kategori Mulai Berkembang (MB) karena anak hanya menghibur teman tertentu, 2 peserta didik $(16,66 \%)$ dalam kategori Belum Berkembang (BB) karena anak tidak menghibur teman yang sedih.

Meningkatkan kecerdaan interpersonal anak dalam kooperatif/kerja sama, terdapat 2 peserta didik $(16,66 \%)$ dalam ketegori Berkembang Sangat Baik (BSB) karena anak melakukan tugas secara bersama, 5 peserta didik $(41,66 \%)$ dalam kategori Berkembang Sesuai Harapan (BSH) karena anak melakukan tugas secara bersama tanpa memilih, 4 peserta didik $(33,34 \%)$ dalam kategori Mulai Berkembang (MB) karena anak melakukan tugas tertentu, 1 peserta didik $(8,34 \%)$ dalam kategori belum berkembang (BB) karena anak tidak melakukan tugas secara bersama.

Berdasarkan hasil pengamatan, diketahui dari 12 anak meningkat kecerdasan interpersonal anak dalam menyesuaikan diri tindakan II terdapat 4 peserta didik $(33,34 \%)$ dalam keteori Berkembang Sangat Baik (BSH) karena anak bersosialisasi dengan tema-teman sejawad dan orang lain, 5 peserta didik $(41,66 \%)$ dalam kategori Berkembang Sesuai Harapan (BSB) karena anak bersosialisasi dengan teman-teman sejawad dan orang lain tanpa memilih, 2 peserta didik (16,66\%) dalam kategori Mulai Berkembang (MB) karena anak hanya bersosialisasi dengan teman-teman tertentu, 1 peserta didik $(8,34 \%)$ dalam kategori Belum Berkembang (BB) karena anak kurang bersosialisasi dengan teman-teman sejawat dan orang lain.

Meningkatkan kecerdasan interpersonal anak dalam empati, terdapat 1 peserta didik $(8,34 \%)$ dalam ketegori Berkembang Sangat Baik (BSB) karena anak menghibur teman yang sedih, 2 peserta didik $(16,66 \%)$ dalam kategori Berkembang Sesuai Harapan (BSH) karena anak menghibur teman yang sedih tanpa memilih, 7 peserta 
didik $(58,34 \%)$ dalam kategori Mulai Berkembang (MB) karena anak hanya menghibur teman tertentu, 2 peserta didik (16,66\%) dalam kategori Belum Berkembang (BB) karena anak tidak menghibur teman yang sedih.

Meningkatkan kecerdaan interpersonal anak dalam kooperatif/kerja sama, terdapat 5 peserta didik $(41,66 \%)$ dalam ketegori Berkembang Sangat Baik (BSB) karena anak melakukan tugas secara bersama, 3 peserta didik (25\%) dalam kategori Berkembang Sesuai Harapan (BSH) karena anak melakukan tugas secara bersama tanpa memilih, 3 peserta didik (25\%) dalam kategori Mulai Berkembang (MB) karena anak melakukan tugas tertentu, 1 peserta didik $(8,34 \%)$ dalam kategori Belum Berkembang (BB) karena anak tidak melakukan tugas secara bersama.

Berdasarkan hasil rekapitulasi, dirata-ratakan ketiga aspek yang diamati dari tindakan I dan II dari siklus I. Hasil tindakan I terdapat 13,88\% dalam ketegori Berkembang Sangat Baik (BSB), 38,88\% dalam kategori Berkembang Sesuai Harapan (BSH), 30,56\% dalam kategori Mulai Berkembang (MB), 16,68\% dalam kategori Belum Berkembang (BB).

Melihat presentase hasil pengamatan tindakan I dan II pada siklus I terhadap Upaya Meningkatkan Kecerdasan Interpersonal Anak Melalui Metode Bermain Peran, jelas terlihat bahwa presentase yang diperoleh dari 3 aspek pengamatan Meningkatkan kecerdasan interpersonal anak yang di nilai dalam menyesuaikan diri, empati,dan kooperatif/kerja sama, mulai ada peningkatan dari siklus I tindakan I yaitu 13,88\% dalam kategori berkembang sangat baik dan tindakan II 27,79\% dalam kategori berkembang sangat baik. Namun peneliti ingin meningkatkan kembali kecerdasan interpersonal anak melalui metode bermain peran menjadi $75 \%$ dalam kategori Berkembang Sangat Baik (BSB) berdasarkan hasil tersebut, peneliti akan melakukan tindakan II.

\section{d. Refleksi Tindakan Siklus I}

Berdasarkan hasil pengamatan yang dilakukan pada aktivitas guru yang masuk dalam kategori yang harus di tingkatkan untuk mencapaik kriteria keberhasilan yang baik. Sedangkan aktivitas anak sekalipun sudah dapat peningkatan dari hasil pra tindakan, sedangkan hasil tindakan siklus I sudah mulai mencapai presentase keberhasilan tindakan. Namun hasil yang diharapkan belum sesuai dengan tujuan penelitian yaitu Meningkatkan Kecerdasan Interpersonal Anak Melalui Metode Bermain Peran. Dalam kategori berkembang sangat baik dengan presentase $75 \%$ yang dicapai.

Hal ini di sebabkan karena masih ada beberapa anak yang yang masuk dalam kategori mulai berkembang dalam tiga aspek pengamatan anak dalam menyesuaikan diri, empati, kooperatif/kerjasama. Selain itu, ada temuan temuan atau kejadian yang didapat selama tindakan berlangsung yang menjadi kelemahan dan perlu diperbaiki pada perencanaan tindakan selanjutnya di RA DWP STAIN Datokarama Palu. 
Tabel 1

Refleksi Tindakan Siklus I Meningkatkan Kecerdasan Interpersonal Anak Melalui Metode Bermain Peran

\begin{tabular}{|c|c|c|c|}
\hline No & Kelemahan & Analisis Penyebabnya & Rekomendasi \\
\hline 1 & $\begin{array}{l}\text { Kemampuan anak } \\
\text { dalam menyesuaikan } \\
\text { diri, empati dan } \\
\text { kooperatif/kerja sama } \\
\text { belum berkembang } \\
\text { dengan baik. }\end{array}$ & $\begin{array}{l}\text { Disebabkan anak masih } \\
\text { canggung dalam berbaur } \\
\text { dengan masyarakat sekolah }\end{array}$ & $\begin{array}{l}\text { Guru/peneliti menerapkan } \\
\text { model pembelajaran bermain } \\
\text { peran sehingga hubungan } \\
\text { interpersoanl anak dapat } \\
\text { ditingkatkan }\end{array}$ \\
\hline
\end{tabular}

Sumber Data : Raudhatul Athfal Dharma Wanita Persatuan STAIN Datokarama Palu

\section{Hasil Pengamatan Siklus II}

Pada tahap tindakan siklus II ini, penulis melakukan proses belajar mengajar di dalam kelas berdasarkan RPPH yang telah penulis buat untuk meningkatkan keceradasan interpersonal anak melalui metode bermain peran, di dalam tindakan siklus II ini. Penulis melakukan tindakan 2 kali pertemuan di RA DWP STAIN Datokarama Palu. untuk meningkatkan kecerdasan interpesonal anak melalui metode bermain peran. Penulis melakukan tindakan I dan II pada siklus II ini, dimulai dengan membuat perencanaan, tindakan, observasi, dan refleksi. saat penyajian materi, peneliti bertindak sebagai pengajar atau guru.

\section{a. Perencanaan}

Pada tahap ini, penilis mempersiapkan tindakan seperti:

1) Memilih materi yang akan diajarkan sesuai dengan tema

2) Membuat rencana kegiatan harian (RPPH)

3) Membuat lembar observasi aktivitas guru dan murid

4) Mempersiapkan alat bantu mengajar dan alat permainan edukatif

5) Membuat tugas yang akan dikerjakan

\section{b. Pelaksanaan}

Melaksanakan proses pembelajaran di dalam kelas berdasarkan RPPH yang telah dibuat, yaitu melaksanakan kegiatan pembuka 30 menit yang dimulai dengan mengucapkan salam, berdoa, membaca surah Annas ayat 1-2 dan Melafalkan Do'a sebelum belajar. Setelah membaca doa masuk kegiatan inti selama 60 menit. Dalam pembelajaran inti selama 60 menit yang dimulai dengan bertanya tentang hari, tanggal, bulan dan tahun, dan dilanjutkan dengan menjelaskan tema hari ini, kemudian kegiatan belajar dan bermain peran dokter-dokter.Setelah selesai pembelajaran, masuk kegiatan istirahat 30 menit masuk kegiatan Berdo'a sebelum dan sesudah makan, Bermain di dalam / di luar kelas. Setelah istirahat masuk kegiatan penutup 60 menit Diskusi kegiatan hari ini, Bernyanyi dan bersyair pulang sekolah, Berdo'a pulang dan Salam. 


\section{c. Observasi}

Penulis melakukan pengamatan terhadap aktivitas anak pada saat proses kegaiatan pembelajaran berlangsung. Hasil pengamatan tindakan I dan II pada aktivitas peserta didik di RA DWP STAIN Datokarama Palu, diketahui dari 12 anak meningkat kecerdasan interpersonal anak melalui metode bermain peran pada menyesuaikan diri melalui tindakan siklus II terdapat 6 peserta didik (50\%) dalam ketegori Berkembang Sangat Baik (BSB) karena anak bersosialisi dengan temateman sejawad dan orang lain, 5 peserta didik $(41,66 \%)$ dalam kategori Berkembang Sesuai Harapan (BSH) karena anak bersosialisasi dengan temanteman sejawad dan orang lain tanpa memilih, 1 peserta didik $(8,34 \%)$ dalam kategori Mulai Berkembang (MB) karena anak hanya bersosialisasi dengan temanteman tertentu, 0 peserta didik $(0 \%)$ dalam kategori Belum Berkembang (BB) karena tidak terdapat anak kurang bersosialisasi dengan teman-teman tertentu.

Meningkatkan kecerdasan interpersonal anak dalam empati, terdapat 8 peserta didik $(66,66 \%)$ dalam ketegori Berkembang Sangat Baik (BSB) karena anak menghibur teman yang sedih, 3 peserta didik (25\%) dalam kategori Berkembang Sesuai Harapan (BSH) karena anak menghibur teman yang sedih tanpa memilih, 1 peserta didik $(8,34 \%)$ dalam kategori Mulai Berkembang (MB) karena anak hanya menghibur teman tertentu, 0 peserta didik $(0 \%)$ dalam kategori Belum Berkembang (BB) karena tidak terdapat anak yang tidak menghibur teman yang sedih.

Meningkatkan kecerdaan interpersonal anak dalam kooperatif/kerja sama, terdapat 6 peserta didik (50\%) dalam Ketegori Berkembang Sangat Baik (BSB) karena anak melakukan tugas secara bersama, 4 peserta didik $(33,34 \%)$ dalam kategori Berkembang Sesuai Harapan (BSH) karena anak melakukan tugas secara bersama tanpa memilih, 2 peserta didik (16,66\%) dalam kategori Mulai Berkembang (MB) karena anak melakukan tugas tertentu, 0 peserta didik (0\%) dalam kategori Belum Berkembang (BB) karena tidak terdapat anak yang melakukan tugas secara bersama.

Berdasarkan hasil pengamatan, diketahui dari 12 anak meningkat kecerdasan interpersonal anak melalui metode bermain peran pada menyesuaikan diri melalui tindakan II terdapat 10 peserta didik $(83,33 \%)$ dalam ketgeori Berkembang Sangat Baik (BSB) karena anak bersosialisasi dengan teman-teman sejawat dan orang lain, 2 peserta didik $(16,66 \%)$ dalam kategori Berkembang Sesuai Harapan (BSH) karena anak bersosialisasi dengan teman-teman sejawad dan orang lain tanpa memilih, 0 peserta didik (0\%) dalam kategori Mulai Berkembang (MB) karena tidak terdapat anak yang hanya bersosialisasi dengan teman-teman tertentu, 0 peserta didik $(0 \%)$ dalam kategori Belum Berkembang (BB) karena tidak terdapat anak kurang bersosialisasi dengan teman-teman tertentu.

Meningkatkan kecerdasan interpersonal anak dalam empati, terdapat 10 (83,33\%) dalam ketegori Berkembang Sangat Baik (BSB) karena anak menghibur teman yang sedih, 2 peserta didik $(16.66 \%)$ dalam kategori Berkembang Sesuai 
Harapan (BSH) karena anak menghibur teman yang sedih tanpa memilih, 0 peserta didik (0\%) dalam kategori Mulai Berkembang (MB) karena tidak terdapat anak yang hanya menghibur teman tertentu, 0 peserta didik $(0 \%)$ dalam kategori Belum Berkembang (BB) karena tidak terdapat anak yang tidak menghibur teman yang sedih.

Meningkatkan kecerdaan interpersonal anak dalam kooperatif/kerja sama, terdapat 10 pesreta didik (38,33\%) dalam ketegori Berkembang Sangat Baik (BSB) karena anak melakukan tugas secara bersama, 2 peserta didik $(16,66 \%)$ dalam kategori Berkembang Sesuai Harapan (BSH) karena anak melakukan tugas secara bersama tanpa memilih, 0 peserta didik (0\%) dalam kategori Mulai Berkembang (MB) karena tidak terdapat anak yang hanya melakukan tugas bersama, 0 peserta didik (0\%) dalam kategori Belum Berkembang (BB) karena tiadk terdapat anak yang tidak melakukan tugas secara bersama.

Berdasarkan hasil rekapitulasi, dirata-ratakan ketiga aspek yang diamati dari tindakan I dan II dari siklus II. Hasil tindakan I terdapat 55,56\% dalam kategori Berkembang Sangat Baik (BSB), 33.33\% dalam kategori Berkembang Sesuai Harapan (BSB), 11,11\% dalam kategori Mulai Berkembang (MB), 0\% dalam kategori Belum Berkembang (BB). Hasil dari tindakan II terdapat 83,34 dalam ketgeori Berkembang Sangat Baik (BSB), 16,66\% dalam kategori Berkembang Sesuai Harapan (BSH), 0\% dalam kategori Mulai Berkembang (MB), 0\% dalam kategori Belum Berkembang (BB).

Melihat presentase hasil pengamatan tindakan I dan II pada siklus II terhadap Upaya Meningkatkan Kecerdasan Interpersonal Anak Melalui Metode Bermain Peran, jelas terlihat bahwa presentase yang diperoleh dari 3 aspek pengamatan Meningkatkan kecerdasan interpersonal anak yang dinilai dalam menyesuaikan diri, empati, dan kooperatif/kerja sama, mulai ada peningkatan dari siklus II tindakan I yaitu 55,55\% dalam kategori berkembang sangat baik dan tindakan II 83,34\%. Hasil presentase tindakan II pada Siklus II telah mencapai keberhasilan yang di harapkan penulis, oleh karena itu, tidak perlu dilakukan perbaikan pada tindakan selanjutnya.

\section{d. Refleksi tindakan siklus II}

Berdasarkan hasil pengamatan yang dilakukan pada aktivitas guru yang masuk dalam kategori baik yang diamati telah masuk dalam kategori baik. Sedangkan aktivitas anak dalam proses pembelajaran telah mencapai presentase keberhasilan tindakan untuk ketiga aspek pengamatan menyesuaikan diri, empati, dan kooperatif/kerja sama. Metode bermain peran telah di terapkan oleh guru dalam kegiatan dan proses pembelajaran telah meningkatkan kecerdasan interpersonal anak melalui metode bermain peran di RA DWP STAIN Datokarana Palu.

\section{B. Pembahasan}

Berdasarkan observasi yang penulis lakukan mulai pra tindakan, siklus I, dan siklus II dapat dibahas sebagai berikut. 


\section{Bahasan Pra Tindakan}

Berdasarkan hasil penelitian pra tindakan dari 12 peserta didik yang menjadi subyek penelitian untuk meningkatkan kecerdasan interpersonal peserta didik pada menyesuaikan diri terdapat 2 peserta didik (16.66\%) dalam kategori Berkambang Sangat Baik, (BSB) karena anak bersosialisai dengan teman-teman sejawad dan orang lain, 3 peserta didik (25\%) dalam kategori Berkembang Sesuai Harapan (BSH) karena anak dapat bersosialisai dengan teman sejawat tanpa memilih, 4 peserta didik (33.34\%) dalam kategori Mulai Berkembang (MB) karena anak hanya bersosialisai dengan teman-teman tertentu, 3 peserta didik (25\%) kategori Belum Berkembang (BB) karena anak kurang bersosialisai dengan teman sejawat dan oarang lain.

Penelitian untuk meningkatkan kecerdasan interpersonal peserta didik pada empati terdapat 1 peserta didik $(8,34 \%)$ dalam kategori Berkambang Sangat Baik (BSB) karena anak menghibur teman yang sedih, 2 peserta didik $(16,66 \%)$ dalam kategori Berkembang Sesuai Harapan (BSH) karena anak menghibur teman yang sedih tanpa memilih, 4 peserta didik $(33,34 \%)$ dalam kategori Mulai Berkembang (MB) karena anak hanya menghibur teman tertentu, 5 peserta didik $(41,66 \%)$ kategori Belum Berkembang (BB) karena anak tidak menghibur teman yang sedih.

Penelitian untuk meningkatkan kecerdasan interpersonal anak pada kooperatif/kerja sama terdapat 2 peserta didik $(16,66 \%)$ dalam kategori Berkambang Sangat Baik (BSB) karena anak melakukan tugas secara bersama, 3 peserta didik (25\%) dalam kategori Berkembang Sesuai Harapan (BSH) karena anak melakuakan tugas secara bersama tanpa memilih, 3 peserta didik (25\%) dalam kategori Mulai Berkembang (MB) karena anak melakukan tugas tertentu, 4 peserta didik $(33,34 \%)$ dalam kategori Belum Berkembang (BB) karena anak tidak melakukan tugas secara bersama.

\section{Bahasan Siklus I}

\section{a. Tindakan I Siklus I}

Diketahui dari 12 anak meningkat kecerdasan interpersonal anak pada menyesuaikan diri melalui tindakan I terdapat 2 peserta didik $(16.66 \%)$ dalam ketgeori Berkembang Sangat Baik (BSB) karena anak bersosialisi dengan temateman sejawad dan orang lain, 3 peserta didik (25\%) dalam kategori Berkembang Sesuai Harapan (BSB) karena anak bersosialisasi dengan teman-teman sejawad dan orang lain tanpa memilih, 4 peserta didik $(33,34 \%)$ dalam kategori Mulai Berkembang (MB) karena anak hanya bersosialisasi dengan teman-teman tertentu, 3 peserta didik (25\%) dalam kategori Belum Berkembang (BB) karena anak kurang bersosialisasi dengan teman-teman tertentu.

Meningkatkan kecerdasan interpersonal anak dalam empati, terdapat $1(83 \%)$ dalam ketegori Berkembang Sangat Baik (BSB) karena anak menghibur teman yang sedih, 6 peserta didik (50\%) dalam kategori Berkembang Sesuai Harapan 
(BSH) karena anak menghibur teman yang sedih tanpa memilih, 3 peserta didik (25\%) dalam kategori Mulai Berkembang (MB) karena anak hanya menghibur teman tertentu, 2 peserta didik $(16,66)$ dalam kategori Belum Berkembang (BB) karena anak tidak menghibur teman yang sedih.

Meningkatkan kecerdasan interpersonal anak dalam kooperatif/kerja sama, terdapat 2 peserta didik $(16,66 \%)$ dalam ketegori Berkembang Sangat Baik (BSB) karena anak melakukan tugas secara bersama, 5 peserta didik $(41,66 \%)$ dalam kategori Berkembang Sesuai Harapan (BSH) karena anak melakukan tugas secara bersama tanpa memilih, 4 peserta didik (33,34\%) dalam kategori Mulai Berkembang (MB) karena anak melakukan tugas tertentu, 1 peserta didik $(8,34 \%)$ dalam kategori Belum Berkembang (BB) karena anak tidak melakukan tugas secara bersama.

\section{b. Tindakan II Siklus I}

Diketahui dari 12 anak meningkat kecerdasan interpersonal anak pada menyesuaikan diri melalui tindakan II terdapat 4 peserta didik $(33,34 \%)$ dalam ketgeori Berkembang Sangat Baik (BSB) karena anak bersosialisi dengan temateman sejawad dan orang lain, 5 peserta didik $(41,66 \%)$ dalam kategori Berkembang Sesuai Harapan (BSH) karena anak bersosialisasi dengan temanteman sejawad dan orang lain tanpa memilih, 2 peserta didik $(16,66 \%)$ dalam kategori Mulai Berkembang (MB) karena anak hanya bersosialisasi dengan temanteman tertentu, 1 peserta didik $(8,34 \%)$ dalam kategori Belum Berkembang (BB) karena anak kurang bersosialisasi dengan teman-teman tertentu.

Meningkatkan kecerdasan interpersonal anak dalam empati, terdapat 1 peserta didik $(8,34 \%)$ dalam ketegori Berkembang Sangat Baik (BSB) karena anak menghibur teman yang sedih, 2 peserta didik $(16,66 \%)$ dalam kategori Berkembang Sesuai Harapan (BSH) karena anak menghibur teman yang sedih tanpa memilih, 7 peserta didik $(58,34 \%)$ dalam kategori Mulai Berkembang (MB) karena anak hanya menghibur teman tertentu, 2 peserta didik $(16,66)$ dalam kategori Belum Berkembang (BB) karena anak tidak menghibur teman yang sedih.

Meningkatkan kecerdaan interpersonal anak dalam kooperatif/kerja sama, terdapat 5 peserta didik $(41,66 \%)$ dalam ketegori Berkembang Sangat Baik (BSB) karena anak melakukan tugas secara bersama, 3 peserta didik (25\%) dalam kategori Berkembang Sesuai Harapan (BSH) karena anak melakukan tugas secara bersama tanpa memilih, 3 peserta didik (25\%) dalam kategori Mulai Berkembang (MB) karena anak melakukan tugas tertentu, 1 peserta didik $(8,34 \%)$ dalam kategori Belum Berkembang (BB) karena anak tidak melakukan tugas secara bersama.

\section{Bahasan siklus II}

\section{a. Tindakan I Siklus II}

Diketahui dari 12 anak meningkat kecerdasan interpersonal anak melalui metode bermain peran pada penyesuaian diri melalui tindakan I terdapat 6 peserta 
didik (50\%) dalam ketgeori Berkembang Sangat Baik (Bsb) karena anak bersosialisi dengan tema-teman sejawad dan orang lain, 5 peserta didik $(41,66 \%)$ dalam kategori Berkembang Sesuai Harapan (BSH) karena anak bersosialisasi dengan teman-teman sejawad dan orang lain tanpa memilih, 1 peserta didik $(8,34 \%)$ dalam kategori Mulai Berkembang (MB) karena anak hanya bersosialisasi dengan teman-teman tertentu, 0 peserta didik $(0 \%)$ dalam kategori Belum Berkembang (BB) karena tidak terdapat anak kurang bersosialisasi dengan teman-teman tertentu.

Meningkatkan kecerdasan interpersonal anak dalam empati, terdapat 8 peserta didik $(66,66 \%)$ dalam ketegori Berkembang Sangat Baik (BSB) karena anak menghibur teman yang sedih, 3 peserta didik (25\%) dalam kategori Berkembang Sesuai Harapan (BSH) karena anak menghibur teman yang sedih tanpa memilih, 1 peserta didik $(8,34 \%)$ dalam kategori Mulai Berkembang (MB) karena anak hanya menghibur teman tertentu, 0 peserta didik $(0 \%)$ dalam kategori Belum Berkembang (BB) karena tidak terdapat anak yang tidak menghibur teman yang sedih.

Meningkatkan kecerdaan interpersonal anak dalam kooperatif/kerja sama, terdapat 6 pesreta didik (50\%) dalam ketegori Berkembang Sangat Baik (BSB) karena anak melakukan tugas secara bersama, 4 peserta didik $(33,34 \%)$ dalam kategori Berkembang Sesuai Harapan (BSH) karena anak melakuakn tugas secara bersama tanpa memilih, 2 peserta didik (16,66\%) dalam kategori Mulai Berkembang (MB) karena anak melakukan tugas tertentu, 0 peserta didik $(0 \%)$ dalam kategori Belum Berkembang (BB) karena tiadk terdapat anak yang tidak melakukantugas seacar bersama.

\section{b. Tindakan II Siklus II}

Diketahui dari 12 anak meningkat kecerdasan interpersonal anak melalui metode bermain peran pada menyesuaikan diri melalui tindakan II terdapat 10 peserta didik $(83,33 \%)$ dalam ketgeori Berkembang Sangat Baik (BSB) karena anak bersosialisi dengan tema-teman sejawad dan orang lain, 2 peserta didik $(16,66 \%)$ dalam kategori Berkembang Sesuai Harapan (BSH) karena anak bersosialisasi dengan teman-teman sejawad dan orang lain tanpa memilih, 0 peserta didik (0\%) dalam kategori Mulai Berkembang (MB) karena tidak terdapat anak yang hanya bersosialisasi dengan teman-teman tertentu, 0 peserta didik $(0 \%)$ dalam kategori Belum Berkembang (BB) karena tidak terdapat anak kurang bersosialisasi dengan teman-teman tertentu.

Meningkatkan kecerdasan interpersonal anak dalam empati, terdapat 10 $(83,33 \%)$ dalam ketegori Berkembang Sangat Baik (BSB) karena anak menghibur teman yang sedih, 2 peserta didik (16.66\%) dalam kategori Berkembang Sesuai Harapan (BSH) karena anak menghibur teman yang sedih tanpa memilih, 0 peserta didik $(0 \%)$ dalam kategori Mulai Berkembang (MB) karena tidak terdapat anak yang hanya menghibur teman tertentu, 0 peserta didik $(0 \%)$ dalam kategori Belum 
Berkembang (BB) karena tidak terdapat anak yang tidak menghibur teman yang sedih.

Meningkatkan kecerdaan interpersonal anak dalam kooperatif/kerja sama, terdapat 10 peserta didik (38,33\%) dalam ketegori Berkembang Sangat Baik (BSB) karena anak melakukan tugas secara bersama, 2 peserta didik $(16,66 \%)$ dalam kategori Berkembang Sesuai Harapan (BSH) karena anak melakukan tugas secara bersama tanpa memilih, 0 peserta didik $(0 \%)$ dalam kategori Mulai Berkembang (MB) karena tidak terdapat anak yang melakukan tugas tertentu, 0 peserta didik $(0 \%)$ dalam kategori Belum Berkembang (BB) karena tidak terdapat anak yang tidak melakukan tugas seacara bersama.

Melalui persentase yang diperoleh dari hasil pengamatan tindakan siklus II di RA DWP STAIN Datokarama Palu jelas terlihat bahwa persentase yang diperoleh dari tiga aspek pengamatan upaya meningkatkan kecerdasan interpersonal anak melalui metode bermain peran dalam aspek menyesuaikan diri, empati, kooperatif/kerja sama, yang telah mencapai keberhasilan tindakan pada penelitian yang diharapkan oleh penulis. Oleh karena itu tidak perlu dilakukan perbaikan pada tindakan selanjutnya atau siklus 3 .

Meningkatkan Kecerdasan Interpesonal Anak Melalui Metode Bermain Peran pada siklus II mencapai keberhasilan itu karena penulis senantiasa memberikan pujian, motivasi, dorongan, memberikan bintang serta semangat agar anak dapat meningkatkan kemampuanya. Dan mengajarkan anak agar tidak malas dalam mengikuti pembelajaran yang sedang berlangsung, dan bagaiman bisa bekerja sama dengan teman untuk bermain yang menyenangkan bersama-sama dan saling membantu untuk membentuk sesuatu yang baik. Meskipun masih ada anak yang belum berhasil mencapai tahap perkembangan sangat baik sesuai dengan harapan penulis. Oleh karena itu, peneliti memutuskan tidak untuk melanjutkan ke tahap berikutnya atau siklus berikutnya, karena peserta didik yag belum berkembang dan berhasil persentasenya sangat kecil. Penelitian tindakan kelas ini, bisa dikatakan berhasil dengan baik karena telah dapat memperbaiki proses pembelajaran yang berdampak dengan upaya meningkatkan kecerdasan interpersonal anak melalui metode bermain peran di RA DWP STAIN Datokarama Palu.

\section{KESIMPULAN}

Berdasarkan hasil penelitian yang telah dijelaskan maka kesimpulan dari penulis ini sebagai berikut :

1. Upaya meningkatkan kecerdasan interpersonal anak melalui metode bermain peran di RA DWP STAIN Datokarama Palu dilakukan dengan 2 siklus, yaitu siklus I dan silus II dengan masing-masing siklus terdiri dari 2 pertemuan. Pada siklus I anak melakukan metode bermain peran dengan bimbingan guru dan 
penulis sedangkan pada silus II anak melakukan metode bermain perandengan teman-temannya tanpa dibimbing oleh guru dan penulis.

2. Meningkatkan kecerdasan interpersonal anak melalui metode bermain peran, yang terdiri dari dua siklus. Pada siklus I meningkatkan kecerdasan interpesonal anak melalui metode bermain peran pada tindakan I persentasenya yaitu 13,88\% dalam kategori Berkembang Sangat Baik (BSB) sedangkan pada tindakan II persentasenya yaitu $27,79 \%$ dalam kategori berkembang sangat baik (BSB). Hal tersebut belum mencapai sesuai harapan peneliti untuk mencapai $75 \%$ dalam kategori berkembang sangat baik. Hasil siklus II di RA DWP STAIN Datokarama Palu tindakan I persentasenya yaitu 55,56\% dala $\mathrm{m}$ kategori berkembang sangat baik (BSB), sedangkan pada tindakan II siklus II persentasenya yaitu $83.33 \%$ dalam kategori berkembang sangat baik (BSB). Hal tersebut telah mencapai sesuai harapan peneliti untuk mencapai $75 \%$ dalam kategori berkembang sangat baik (BSB).

\section{SARAN}

Berdasarkan hasil kesimpulan yang telah dijelakan sebelumnya, ada beberapa saran dari penulis antara lain:

1. Guru selayaknya menciptakan pembelajaran yang menarik dengan menggunakan metode pembelajaran yang berfariasi diantaranya metode bermain peran.

2. Bagi sekolah, sekolah dapat mengembangkan program untuk meningkatkan kecerdasan interpersonal anak seperti menerapkan metode bermain peran, serta kegiatan pembelajaran lain yang menunjang anak bersikap patuh dan taat pada peraturan sekolah berupa sikap disiplin dan bertangung jawab atas tugas yang diberikan.

3. Bagi peneliti selanjutnya, penelitian tentang meningkatkan kecerdasan interpersonal anak melalui metode bermain peran masih banyak kekurangan dan jauh dari sempurna. Oleh karena itu, peneliti lain hendaknya termotifasi lebih untuk melanjutkan dan melengkapi penelitian dengan mengunakan metode sentra media pembelajaran yang lebih bervariasi untuk meningkatkan kecerdasan interpersonal anak.

\section{DAFTAR PUSTAKA}

Undang-undang Nomor 20 Tahun 2003, Tentang Sistem Pendidikan nasional Bab 1, pasal 1, Butir 14, (2003) 
Winda Gunarti, S.Pd, Lilis Suryani, S.Pd, Azizah Muis, S.Pd, Metode Pengembangan Perilaku dan Kemampuan Dasar Anak Usia Dini (Jakarta: Universitas Terbuka, 2010).10.11 